Economics Series

No. 120, October 2011

Trade in Environmental Goods, with Focus on Climate-Friendly Goods and Technologies

ZhongXiang Zhang

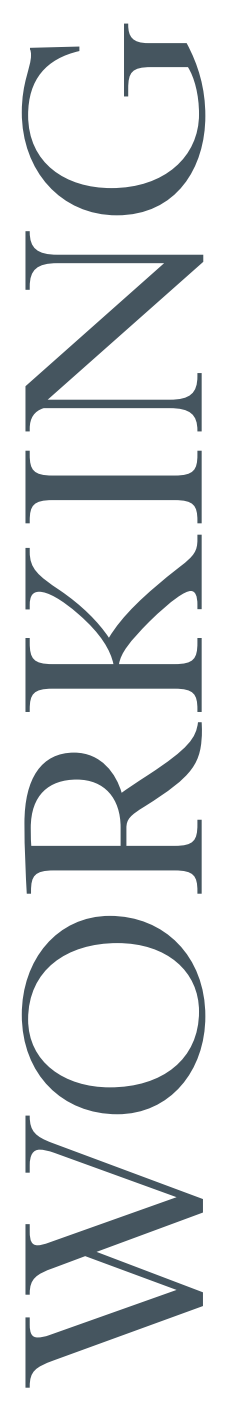

E. E A S T - W EST C E N T E R 
The East-West Center promotes better relations and understanding among the people and nations of the United States, Asia, and the Pacific through cooperative study, research, and dialogue. Established by the U.S. Congress in 1960, the Center serves as a resource for information and analysis on critical issues of common concern, bringing people together to exchange views, build expertise, and develop policy options.

The Center's 21-acre Honolulu campus, adjacent to the University of Hawai'i at Mānoa, is located midway between Asia and the U.S. mainland and features research, residential, and international conference facilities. The Center's Washington, D.C., office focuses on preparing the United States for an era of growing Asia Pacific prominence.

The Center is an independent, public, nonprofit organization with funding from the U.S. government, and additional support provided by private agencies, individuals, foundations, corporations, and governments in the region.

East-West Center Working Papers are circulated for comment and to inform interested colleagues about work in progress at the Center.

For more information about the Center or to order publications, contact:

Publication Sales Office

East-West Center

1601 East-West Road

Honolulu, Hawai‘i 96848-1601

Telephone: 808.944 .7145

Facsimile: 808.944.7376

Email: EWCBooks@EastWestCenter.org

Website: EastWestCenter.org 
VE $\frac{\text { E A S T - W E S T C E N T E R }}{\text { Collaboration + expertise - leadership }}$

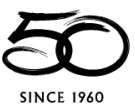

SINCE 1960
Economics Series

No. 120 , October 2011

\section{Trade in Environmental Goods, with Focus on Climate-Friendly Goods and Technologies}

\author{
ZhongXiang Zhang
}

ZhongXiang Zhang is a senior fellow at the East-West Center. Currently, he is a co-editor of both Environmental Economics and Policy Studies (the official journal of the Society of Environmental Economics and Policy Studies) and International Journal of Ecological Economics and Statistics, and serves on the editorial boards of nine leading international journals and two Chinese journals. Eleven of his publications are cited by IPCC Climate Change 2001: Mitigation and IPCC Climate Change 2007: Mitigation of Climate Change.

East-West Center Working Papers: Economics Series is an unreviewed and unedited prepublication series reporting on research in progress. The views expressed are those of the author(s) and are not necessarily those of the East-West Center. Working Papers are available for free in PDF format on the Center's website at EastWestCenter.org/ewcworkingpapers. To order print copies (\$3.00 each plus shipping and handling), contact the Center's Publication Sales Office. 


\title{
Trade in Environmental Goods, with Focus on Climate-Friendly Goods and Technologies
}

\author{
ZhongXiang Zhang, Ph.D in Economics \\ 张中祥 美国东西方中心研究部资深研究员、经济学博士 \\ Senior Fellow \\ Research Program \\ East-West Center \\ 1601 East-West Road \\ Honolulu, HI 96848-1601 \\ United States \\ Tel: $+1-808-9447265$ \\ Fax: +1-808-944 7298 \\ Email: ZhangZ@EastWestCenter.org
}

\begin{abstract}
Paragraph 31(iii) of the Doha Ministerial Declaration mandates to the liberalization of environmental goods and services. This mandate offers a good opportunity to put climate-friendly goods and services on a fast track to liberalization. Agreement on this paragraph should represent one immediate contribution that the WTO can make to fight against climate change. This paper presents the key issues surrounding the liberalization of trade in climate-friendly goods and technologies in WTO environmental goods negotiations. It begins with discussing what products to liberalize and how. Given that WTO Members are divided by this key issue, the paper explores options to move current negotiations on the liberalization of trade in environmental goods and technologies forward, both within and outside the WTO. Recognizing that there is no one-size-fits-all strategy for tariff liberalization for all countries and for all environmental goods, the paper suggests the need for a high degree of flexibility to accommodate different situations and stakes in the liberalization of trade in environmental goods. Given that there are simply not enough environmental markets or these markets are weak in many developing countries, the paper emphasizes that creating markets for environmental goods in developing countries is far more important than just improving market-access conditions for associated goods, and discusses how to best serve the interests and concerns of developing countries.
\end{abstract}

JEL classification: F18, F13, P28, Q42, Q48, Q56, Q54, Q58, Q48

Keywords: Environmental goods and services, Low-carbon goods and technologies, Market access, Doha Round, WTO, Renewable energy technologies 


\section{Introduction}

The global market for environmental goods and services (EGS) is huge and has been growing rapidly. Depending the definitions and coverage, its size is estimated to be at least about US\$ 700 in 2006 by Environmental Business International (Japan Ministry of the Environment, 2008) and as much as $£ 3.046$ trillion in 2007/08 by the UK Department for Business Enterprise and Regulatory Reform (2009). This high end of the estimated market size accounted for about 10 per cent of global GDP. Negotiations on "the reduction or, as appropriate, elimination of tariff and non-tariff barriers to environmental goods and services" mandated under Paragraph 31(iii) of the Doha Ministerial Declaration (DMD) are to promote further market development of global environmental goods and services, by expanding current supply and technological upgrades of goods and services and making them affordable to consumers. Given that growing consensus that climate change has the potential to seriously damage our natural environment and affect the global economy, this mandate offers a good opportunity to put climate-friendly goods and services on a fast track to liberalization to address one of the world's most pressing long-term threats to future prosperity and security. As the Director-General of the World Trade Organization (WTO) puts it, an agreement on this paragraph should represent one immediate contribution that the WTO can make to fight against climate change (Lamy, 2008).

Climate-friendly technologies (or goods) refer to those the production or the utilization of which reduce climate risks to a greater extent than alternative technologies for producing the same product (or alternative products that serve the same purpose). Climate-friendly technologies include those aimed at improving energy efficiency or increasing energy generation from new and renewable sources and goods. Liberalizing such climate-friendly technologies, goods and services contributes not only to increasing the choices available for importing countries, but also to lowering the costs of those choices for those countries to either comply with existing and future greenhouse gas (GHG) emission commitments or to limit the growth of GHG emissions. The resulting market expansion from trade liberalization will put a downward pressure on prices in home country markets and increase competition between imported and domestic goods, thus further lowering the compliance costs. By increasing the dissemination of climatefriendly goods and technologies at a lower cost, trade liberalization will make it less difficult to set stringent GHG emission targets beyond 2012, given that the world's GHG emissions should be cut at least in half by 2050 which the IPCC (2007) argues is necessary in order to avoid dangerous climate change consequences.

This paper will focus on environmental goods (EGs), as that is the area in which negotiations within WTO have to date been more active. This by no means undermines the importance of environmental services in preserving the environment and mitigating climate change. Indeed, many services directly address climate change mitigation. In its discussion and analysis, the paper makes use of official WTO documents, which include submissions by Members and their synthesis by the WTO Secretariat and minutes of meetings, to illustrate the divergent negotiating positions of Members, in particular those representative Members, on an issue that still remains very much open. These divergent negotiating positions not only exemplify challenges ahead and uncertainty about negotiations on the desired degree and level of trade liberalization on EGs, and more 
importantly suggest the need for a high degree of flexibility to accommodate different situations and stakes in the liberalization of trade in EGs.

The paper is structured as follows. Section 2 discusses a variety of approaches in the current negotiations on the liberalization of trade in EGs. Section 3 explores options to move such negotiations forward. Section 4 presents key findings and conclusions.

\section{Approaches to the EG Negotiations: What Products to Liberalize and How?}

\subsection{Negative Approach versus Positive Approach}

To identify which goods and services to ban or promote, a basic distinction can be drawn between negative and positive approaches. A negative approach would be to identify specific goods and services that countries should be required to ban from trade. The Montreal Protocol on Substances that Deplete the Ozone Layer, which was signed in 1987 and has since been amended and strengthened (UNEP Ozone Secretariat, 2000), takes this approach. The Montreal Protocol uses trade measures as one enforcement mechanism among several policy instruments for achieving its aim of protecting the ozone layer. Parties to the convention are required to ban trade with non-parties in ozonedepleting substances (ODS), such as chlorofluorocarbons (CFCs), in products containing them (e.g. refrigerators), and potentially in products made with but not containing CFCs, such as electronic components. This latter provision has not yet been implemented primarily because of problems of detection, and also because of the small volumes of CFCs involved. These trade measures have been extended gradually to all the categories of ozone-depleting substances covered by the Montreal Protocol (Brack, 1996; Zhang, 1998). Accompanied with finance and technology transfer mechanisms, this approach has been effective in phasing out ODS and contributing to the recovery of the ozone layer (Zhang, 2009).

It is clear which products must be banned under product-specific agreements such as the Montreal Protocol, but it is less straightforward to identify products that should be banned in relation to carbon abatement and climate change mitigation. Every product or technology causes environmental harm or affects the climate to some degree. A climatefriendly product or technology is just a concept of relative environmental performance. Such a product or technology tends to be sector- and country-specific, and is subject to change over time. For example, natural gas is less carbon-polluting than coal. Shifting to natural gas has been indentified as part of the solution for climate change mitigation. This has been the main reason why Qatar (2003), in its submission to WTO, has proposed liberalizing natural gas and natural-gas-related technologies as a way to reduce GHG emissions. But natural gas is more carbon-polluting than wind power that emits zero carbon emissions when operating. A coal-fired power plant is more carbon-polluting than one which uses natural gas, but if coupled with carbon capture and storage (CCS) technology, it is more climate-friendly than a natural-gas-fired power plant without CCS. Besides, a country's choice of fuels and technologies depends to a large extent on its resource endowments and their relative prices. The fact that countries like China and India use more coal is not because they prefer it, but because of their abundant supplies of coal and its relatively lower price compared with its more environmentally friendly substitutes. Thus, while some countries or regional agreements (e.g. the North American 
Free Trade Agreement) may have a negative list of services or of investments in certain technologies which are restricted, it is most unlikely that countries will broadly agree on a list of goods that need to be banned. Moreover, arguably, for the purpose of meeting a climate change mitigation objective, any likely ban or restriction would tend to be on goods that emit high levels of GHGs. This will face resistance from Members that object to the use of trade restrictions based on non-product related process and production methods (PPMs), partly because it is difficult for customs officials to distinguish between high and low GHG-emitting products unless Members would be able to establish an acceptable labeling regime - which would in turn rely on those Members that are not in favor of such non-product related PPM distinctions anyway. In addition, there is uncertainty about the WTO compatibility of distinguishing a product based on the way that product is produced, rather than on the final product's characteristics. There is also controversy over whether WTO jurisprudence has moved beyond the PPM concept (Zhang, 2004; Zhang and Assunção, 2004; Howse and Van Bork, 2006; Zhang, 2010c). ${ }^{1}$ Thus a negative approach will not necessarily work in a post-2012 climate regime.

By contrast, a positive approach, which seeks to identify certain goods and services for enhanced market access, holds some promise. Establishing a list of goods, technologies and services in which trade is encouraged has its own problems, but is easier than having a common list of goods, technologies and services that need to be banned.

\subsection{List, Project, Integrated and Request-Offer Approaches}

Under the negotiating structure by the Trade Negotiations Committee in February 2002, negotiations on EGs have been taking place in the Committee on Trade and Environment in Special Session (CTE-SS) (Steenblik, 2005; Harashima, 2008). Such negotiations aim to create a WTO-agreed list of such goods that would then be turned over to the Negotiating Group on Non-Agricultural Market Access (NAMA) to negotiate tariff reductions and/or elimination. The question then is which EGs should be encouraged. Identifying them depends on their definition. Given their conceptual complexities and a lack of consensus on their definition, WTO Members have persistently disagreed over how to identify which EGs should be subject to trade liberalization. Four approaches, namely list, project, integrated and request-offer approaches, have been proposed to define EGs in the WTO negotiations (WTO, 2005; Argentina and Brazil, 2010). Because all other three approaches originate from the list approach, we start with the list approach.

\footnotetext{
${ }^{1}$ Some analysts (e.g., Howse and Van Bork, 2006) have argued that WTO jurisprudence has moved beyond the PPM concept. The Shrimp-Turtle dispute settlement reasoning, if sustained, would permit WTO Members to invoke the GATT (General Agreement on Tariffs and Trade) Article XX exemptions to regulate imports on the basis of non-product related PPMs to accomplish environmental objectives both outside their jurisdiction and in the global commons - and perhaps to achieve other social objectives (Morici, 2002). Moreover, an OECD study by Steenblik et al. (2005) has suggested that developing countries have substantial export potential, particularly when PPMs are included. It should be pointed out, though, that there is no universally accepted interpretation of the Appellate Body decision (Zhang, 2004). Other analysts (e.g., Jackson, 2000) argue that such a conclusion that PPMs no longer violate WTO by their very nature is premature legally or has been insufficiently debated and tested in the scientific literature.
} 
And our discussions on this approach are more elaborated than discussions on other three approaches.

\section{List approach}

The list approach proposes the establishment of a multilaterally agreed list of environmental goods. The Organization for Economic Cooperation and Development (OECD) advocates a list-based approach, whereby goods and services on an agreed list will gain enhanced market access through the elimination or reduction of bound tariffs and non-tariff barriers (NTBs) permanently and on a most-favored-nation (MFN) basis. Such lists have been produced by the OECD and by the Asia-Pacific Economic Cooperation (APEC) group. While the two lists were developed for purposes other than the WTO negotiations, some WTO Members, in the development of their lists, have used as “reference points" the OECD and/or APEC definitions (WTO, 2005).

There are 164 goods on the OECD list at the Harmonized Commodity Description and Coding System (HS) 6-digit level, compared with 109 on the APEC list (WTO, 2002). The OECD list appears to be about 50 per cent longer than the APEC list. This difference in the number of goods results largely from the differing objectives of and procedures for generating the two lists (Steenblik, 2005). The OECD list was the result of an exercise intended to illustrate, primarily for analytical purposes, the scope of the environmental industry. It was created deductively, starting from general categories based on classifications in the environmental industry manual (OECD and Eurostat, 1999), and adding more specific examples, where available, in order to produce an estimate of average tariffs on a previously undefined class of goods. By contrast, the APEC approach started with nominations. This yielded a list of goods, which was then arranged according to an agreed classification system. Given that the aim of the APEC list was to obtain more favorable tariff treatment for environmental goods, APEC economies limited themselves to specific goods that could be readily distinguished by customs agents and treated differently for tariff purposes (Steenblik, 2005). The two lists have 54 goods in common, accounting for 27 per cent of the goods in the combined lists. However, 50 goods on the APEC list do not appear on the OECD list, while 68 goods on the OECD list do not appear on the APEC list. The main difference between the two lists is that only the OECD list contains minerals and chemicals for water/waste treatment, while the APEC list includes a relatively more extensive set of goods needed for environmental monitoring and assessment. The OECD list also contains a large number of environmentally preferable products (Steenblik, 2005). Taking the OECD or APEC lists of EGs as reference points, the so-called "Friends of Environmental Goods" group of countries, comprising Canada, the EU, Japan, the Republic of Korea, New Zealand, Norway, Switzerland, Chinese Taipei, and the United States proposed in April 2007 a list of 153 products. Just prior to the United Nations Climate Change Conference in Bali in December 2007, the EU and the United States submitted a joint proposal at the WTO calling for trade liberalization of 43 climate-friendly goods that were identified by the World Bank (2007) from a list of the Friends' 153 products. This proposal aims to secure a zero tariff for these climate-friendly goods by 2013 in developed and emerging economy Members. Least developed countries are excluded from the proposal as a response to developing counties' criticism of an across-the-board elimination. 
Many developing countries have consistently expressed concerns about the use of the two lists of environmental goods slated for expedited liberalization, noting that a number of products on such the two lists are primarily of export interest to industrialized countries, thus compromising the development dimension. ${ }^{2}$ As stated by Cuba (2005) in its submission, the use of the APEC and OECD lists as reference for preparing a potential multilateral list has failed to serve the interests of developing countries in that it benefits developed country export products and services. In case of the goods included in APEC list, for example, the developed countries make up 79 per cent of environmental goods exports, the developing countries about 20 per cent and the least developed countries less than one percent (Bora and Teh, 2004). The Indian Ambassador was quoted as saying that this EU-United States proposal was "a disguised effort at getting market access through other means and does not satisfy the mandate for environment” (ICTSD, 2007a).

China has suggested creating two lists of different sets of commitments. Taking into consideration the needs of developing countries' development and the vulnerability of their domestic industries in the area of environmental goods, China (2004) in its submission has proposed the establishment of a development list to better reflect the development dimension of trade liberalization. Such a list is selected by developing countries from a common list that includes specific product lines, on which there is consensus that they constitute environmental goods. These selected products would be exempted from or subject to a lower level of reduction commitments. ${ }^{3}$

\section{Project approach}

Another sticking point is related to the issue of dual use, in that many product categories proposed on an EGs list include, at the HS 6-digit level, other products that have nonenvironmental uses in addition to environmental uses. In response, India (2005a,b) has advocated a project-based approach, whereby each WTO Member would designate a national authority to select environmental projects based upon criteria developed by the Special Session of the Committee on Trade and Environment and whose domestic implementation would be subject to WTO dispute settlement. The EGs and services required for a selected environmental project would temporarily enjoy preferred market

\footnotetext{
${ }^{2}$ The United States Trade Representative rejected complaints that the EU-United States list consisted only of products of export interest to industrialized countries, pointing out that in 2006 the United States was in fact a net importer of the 43 products, with US\$18 billion in imports of such products, surpassing exports by US\$3 billion, and citing China and Mexico as the two top sources for those products (ICTSD, 2007c).

${ }^{3}$ The practical use of China's proposal is open to debate. Singh (2005) argues that China's proposal for preparing separate common and developmental lists to protect infant industries may actually not be the most pragmatic way to reflect special and differential treatment. From the point of view of the negotiations, a development list approach could actually bring more complexities. Given that the economic development level of each of the WTO Members is different and so are their priorities for protection of domestic industries, it is quite possible that with this approach most items that appear in the common list might also appear in the development list, as different countries would want exemptions for different products. Put simply, it would be quite a difficult task to capture all developing countries' special protection needs in one such list.
} 
access for the duration of the project. India has argued that the project approach would ensure that the approved EGSs are used for environmental purposes, thus addressing dual-use issues associated with a list-based approach, and would bring positive measures like capacity building and technology transfer. India's proposal, aimed at finding a reasonable balance between environmentally meaningful commitments and the broad application of EGSs across Members, is conceptually innovative, and may be appealing, in particular to WTO Members that lack much negotiating leverage to solve access problems caused by regulation or subsidization in major markets. However, the devil is in the details. This approach is more difficult and requires more resources to operate in practice than a list-based approach. It is also criticized by the "Friends of Environmental Goods” group for failing to offer predictable and permanent liberalization, a criticism that also holds true for the integrated approach.

\section{Integrated approach}

Argentina (2005) has proposed an integrated approach that aims to bridge the gap between the list approach and project approach. It resembles the project approach but with multilaterally agreed pre-identified categories of goods used in the approved projects. Given the World Bank's suggestion to grant priority to products, technologies and services imported for CDM projects (World Bank, 2007) and the WTO DirectorGeneral's statement that trade barriers stand in the way of the CDM (Lamy, 2009), Argentina (2009) emphasizes the link between trade liberalization and CDM projects, providing a specific example of the implementation of this approach to CDM projects. Argentina has argued that linking the integrated approach with CDM projects would encourage the direct use of goods, the environmental objectives of which are climate change mitigation and adaptation, thus preventing dual or multiple usage and ensuring that liberalization effectively contributes to climatic improvement and sustainable development. At the same time it would help to reduce the costs of setting up CDM projects and promote the transfer of technologies to developing countries, thus facilitating the development of domestic capacity in the sector.

\section{Request-offer approach}

Brazil has suggested a request-offer approach, whereby countries would request specific liberalization commitments from each other on products of interest to them and then extend tariff cuts deemed appropriate equally to all WTO Members on an MFN basis. Brazil's proposal would not limit environmental goods to industrial goods, but would include agricultural products, such as biofuels, in the EGS negotiations as well. Brazil has argued that this approach follows along the lines of previous GATT/WTO negotiations and takes into account developing country interests more adequately than the common list put forward by the EU-United States submission (ICTSD, 2007a,b). An analysis of the Friends' 153 EGs list by Jha (2008) indicates that a handful of developing countries are among the top 10 importers and exporters in various categories of EGs relevant to climate change mitigation. Based on these findings, she suggests that these countries could usefully engage in a request-offer approach to ensure trade gains. In this way, while the benefits of trade liberalization may be multilateralized, the cost would be borne by only a few players. These would be the very players that have a lot more to gain through liberalization. 
All these different arguments clearly suggest that some WTO Members have yet to be convinced of the climate change mitigation credentials of some of the products that EU and the United States have proposed. Moreover, advancing technologies will inevitably eclipse the continuing merits of some existing products. According to an estimate by the OECD (2005), half of existing EGs will be replaced within 15 years. Thus, an exclusive focus on the liberalization of these existing products raises the risk of being locked into current patterns of international trade in technologically advanced climate change mitigation products (i.e. producers of technology and importers of that technology). To better reflect the reality of the evolution of environmental goods and technological change and encourage technological innovation in a field where evolution in technologies is the key to successfully addressing environmental challenges, New Zealand, the Commission of the European Communities, and Switzerland have suggested that an agreed list of environmental goods should be considered a "living list" and that a review process of product coverage should be set up to update and expand the list (WTO, 2005). Indeed, issues related to the advancement of technology are not confined to EGs. Sectoral agreements like the 1996 Information Technology Agreement and the Agreement on Trade in Pharmaceutical Products under the Uruguay Round have a mandate to review and update their product coverage on a regular basis (see Kim (2007) for discussions on the review process of these agreements). Furthermore, the developing world is in search of both an economic and an environmental gain through these negotiations under the Doha Round - and rightly so (Lamy, 2008). Even though these negotiations are on environmental issues, they must nevertheless deliver a trade gain if they are being conducted through the Doha Round of the WTO.

\section{Potential Ways to Move the EG Negotiations Forward}

\subsection{Amending HS Codes and Creating Ex-headings to Clarify Product Coverage and Descriptions}

It is important to note that the mandate under Paragraph 16 of the DMD is applicable to environmental goods as well. Paragraph 16 of the DMD guides NAMA negotiations and mandates special attention to "products of export interest to developing countries" as well as requires the "special needs and interests of developing and least developed country participants," to be taken into account. UNCTAD (1995) proposes environmentally preferable products (EPPs) as a trade opportunity for developing countries. EPPs are defined as products that, from a life-cycle perspective, cause significantly less "environmental harm" than alternative products that serve the same purpose, or products the production and sale of which contribute significantly to the preservation of the environment (UNCTAD, 1995). UNCTAD (2005) has further compiled a core list of EPPs. According to this UNCTAD study, there are significant export opportunities for developing countries in a large number of low-tech EGs in its core list of EPPs. The inclusion of EPPs in the EGS negotiations raise the concerns about processes and production methods. The majority of WTO Members have argued against the use of criteria based on non-product-related PPMs to select products for the negotiations. Ecolabeled products and others made with environmentally friendly processes, as well as organic products, are clear case of PPMs and hence are beyond the scope of the 
negotiations (Singh, 2005). Moreover, such EGs also happen to be dual-use products (Hamwey, 2005).

However, most developing countries are hesitant to liberalize bound tariffs on dual-use products due to concerns about the adverse impact of such broader liberalization on their established domestic industries and jobs and, in some cases, on their tariff revenues that continue to represent a large portion of government revenue ${ }^{4}$ (ICTSD, 2008; World Bank, 2007). They insist on applying a single end-use parameter in screening EGs, and only those indentified EGs based on this parameter would then be taken up for tariff reduction negotiations (Howse and Van Bork, 2006).

Isolating products of single environmental use requires assigning clearer $\mathrm{HS}$ codes or product descriptions for environmental goods. The HS allows countries to track trade volumes and tariff levels. The more digits there are in a code, the more specific is the description of the product. Currently, HS numbers for products are only harmonized cross WTO Members up to the six digit level. However, there are only a very few cases in which there is an (almost) perfect match between a single-use EG and a HS code at the six digit level. HS 841011 and HS 841012 (hydraulic turbines) and HS 850231 (wind powered electricity generating sets) are among a few cases that can pass the single-use test (Vossenaar, 2010; Vykhylaev, 2010). In most cases, however, HS product categories at the six digit level contain products that have both non-environmental uses and environmental uses. In these cases, a single-use EG may represent only a very small portion, if any, of trade of all products included in a specific 6-digit HS code. Take a windmill pump as a case in point. A windmill pump is clearly indentified as a single-use EG. It is part of HS 841381, which includes other pumps. The Harmonized Tariff Schedule of the United States breaks down HS 841381 into various sub-positions, including 8413.81.00.30 (household water systems, self-contained; and windmill pumps). During the 2007-2009 period, imports of pumps under the provisions of this 10-digit code accounted for just 1 per cent of the value of US imports of pumps included in HS 841381, and windmill pumps were only an unknown part of this 1 per cent (USITC, 2009; Vossenaar, 2010). This exemplifies that fast-tracking pumps of multiple use in a specific 6-digit HS code under the EGS mandate would be difficult to justify.

Clearly, identifying the so-called "ex-outs" of single environmental use, which, in the language of trade negotiations, refer to those goods that are not separately identified at the 6-digit level of the HS code and have to be identified in national tariff schedules at the 8- or 10-digit level, needs to go beyond the 6-digit level. However, no uniform code exists beyond this level. So, as product descriptions get more specific, different WTO Members use different codes and descriptions. To identify and liberalize specific goods of single environmental use, including those climate mitigation goods, WTO Members need to harmonize at least the ex-out product descriptions cross countries. However, harmonizing HS codes beyond the six digit level will be time-consuming and would not be viable, given the short time horizon for a possible conclusion of the Doha Round and the timing of review cycles of the World Customs Organization, which considers HS amendments once every five years, with the latest amendment in June 2004 and entered into force on January 1, 2007. It is not evident that the desire to enable better targeted and

\footnotetext{
${ }^{4}$ According to the WCO (2003), customs collects over 50 per cent of all government revenues in many developing countries.
} 
deeper tariff reduction for EGs would be deemed sufficiently important to introduce subdivisions.

Another option to operationalize the use of "ex-outs" is to create ex-headings in national customs nomenclatures. Given that each country has different sub-headings within its national customs nomenclatures, if this option is to be considered, countries should agree to a process to ensure the consistency of the product descriptions and encoding of ex-heading goods across countries, so that including ex-heading goods would not cause classification problems at the border (Kim, 2007).

\subsection{Alternative Options to Accelerate Negotiations on Liberalization of Trade in EGs}

What are the other options that need to be explored to accelerate liberalization of trade in EGs? Arguably, countries are likely to agree upon a narrow choice of climate-friendly products that would be acceptable to a broader range of countries rather than a broader range of products that would be acceptable to only a few countries. It would be most efficient to start by identifying a single list of specific goods that all Members can agree on as a basis for further negotiations. One way forward along this line is to focus initially on specific EGs sectors in which the interests of both developed and developing countries coincide in fostering trade liberalization. Increasing energy efficiency is widely considered the most effective and lowest cost means of cutting GHG emissions, and trade in renewable energy equipment in developing countries appears sensitive to tariff reductions (Jha, 2008). Moreover, industrialized countries are set to take on higher proportions of renewable energies in their energy mix, either in order to comply with their GHG emission targets or with the aim of reducing their dependence on foreign oil, or both. Thus the initial round of liberalization should include renewable energy products and energy-efficient technologies. The World Bank (2007) estimates that the removal of tariffs for four basic clean energy technologies (clean coal, energy-efficient lighting, solar and wind power) covering 12 specific EGs in the 18 largest GHG-emitting developing countries would result in a trade gain of up to 7.2 per cent. The trade gain could be boosted by as much as 13.5 per cent if non-tariff barriers to those technologies were also removed (see Table 1). These gains, which were calculated based on a static trade analysis, were considerably underestimated because they failed to take into account the dynamics of these EGs (i.e. trends in growth of their export levels and the size of their world export market). In addition to the trade gains, using these more climate-friendly technologies and products to replace those that are more GHG-polluting will translate into a significant reduction in GHG emissions. Therefore, clearly, liberalizing trade in low-carbon goods and technologies would serve both trade and climate mitigation interests, not to mention its contribution to reductions in conventional pollutants and the resulting health risks. 
Table 1 Estimated benefits of removal of tariffs and non-tariffs barriers to four select clean energy technologies covering 12 environmental goods

\begin{tabular}{lll}
\hline $\begin{array}{l}\text { Technologies } \\
\text { (HS codes) }\end{array}$ & \multicolumn{1}{c}{ Increases in trade volumes (\%) } \\
\cline { 2 - 3 } & Removal of tariffs & $\begin{array}{l}\text { Removal of tariffs and non- } \\
\text { tariffs barriers }\end{array}$ \\
\hline $\begin{array}{l}\text { Clean coal (HS codes } \\
\text { 840510, 840619, 841181, } \\
\text { 841182, 841199) }\end{array}$ & 3.6 & 4.6 \\
$\begin{array}{l}\text { Wind (HS codes 848340, } \\
\text { 848360, 850230) }\end{array}$ & 12.6 & 22.6 \\
$\begin{array}{l}\text { Solar photovoltaic (HS } \\
\text { codes 850720, 853710, }\end{array}$ & 6.4 & 13.5 \\
$\begin{array}{l}\text { 854140) } \\
\text { Energy-efficient lighting } \\
\text { (HS code 853931) }\end{array}$ & 15.4 & \\
Total & 7.2 & 63.6 \\
\hline
\end{tabular}

Source: World Bank (2007).

Table 2 Pipeline of CDM projects at the validation stage or beyond (as of 1 September 2011)

\begin{tabular}{|c|c|c|c|c|}
\hline \multirow[t]{2}{*}{ Region } & \multicolumn{2}{|c|}{$\begin{array}{l}\text { CDM projects at validation } \\
\text { or beyond }\end{array}$} & \multicolumn{2}{|c|}{$\begin{array}{l}\text { Projected certified } \\
\text { emission reductions by } \\
2012\end{array}$} \\
\hline & Number & $\%$ & $\begin{array}{l}\text { Million tons } \\
\mathrm{CO}_{2}\end{array}$ & $\%$ \\
\hline Latin America & 948 & 14.1 & 375.6 & 13.8 \\
\hline Asia and Pacific & 5453 & 81.1 & 2174.2 & 79.7 \\
\hline China & 2813 & 41.8 & 1496.0 & 54.8 \\
\hline India & 1735 & 25.8 & 418.3 & 15.3 \\
\hline Europe and Central Asia & 72 & 1.1 & 40.2 & 1.5 \\
\hline Africa & 178 & 2.6 & 97.9 & 3.6 \\
\hline Middle-East & 73 & 1.1 & 40.5 & 1.5 \\
\hline Total & 6724 & 100.0 & 2728.3 & 100.0 \\
\hline
\end{tabular}

Source: UNEP Risoe Center (2011).

A "procedural" area of accelerated liberalization relates to products, technologies and services used in small-scale CDM projects (e.g. micro-hydro projects, efficient 
cooking and efficient lighting) and programmatic CDM. ${ }^{5}$ The CDM has been partially successful (Zhang, 2008): the global number of CDM projects registered and in the pipeline by 1 September 2011 totaled 6724 (UNEP Risoe Center, 2011) - well above what was envisioned by countries when they negotiated, designed and launched this mechanism. However, the lion's share of these CDM projects has gone to a handful of major developing countries like China and India, whereas many countries, especially those in sub-Saharan Africa, have been left out (see Table 2). ${ }^{6}$ One of the main reasons is that the transaction costs associated with the CDM project cycle have seriously hampered small-scale CDM projects in these countries. Although registration fees are set considerably lower for small-scale CDM projects, and simplified methodologies and procedures are also set for those projects, many other transaction costs are independent of project size and will thus have a bigger relative impact on small-scale CDM projects. Programmatic CDM, which bundles together small-scale CDM projects or a programme of activities, makes a better contribution to sustainable development and communality empowerment than a single CDM project, but it entails high transaction costs (Zhang and Maruyama, 2001; Paulsson, 2009). Thus, liberalizing products, technologies and services in this area could reduce equipment costs and contribute to lowering transaction costs for potential investors. This would facilitate capitalizing on the untapped potential of programmatic CDM and extend the mechanism's reach in terms of both project type and geographical spread. ${ }^{7}$

Even in these two areas, developing country concerns about the possible impacts of liberalization on their domestic industries would need to be addressed before a deal could be hammered out. This applies particularly to environmental goods and technologies that developing countries are not competitive in producing. The question then is whether it is better for home countries to import such goods and technologies at lower costs to foster greater domestic environmental improvements or to keep a certain level of protection to build up domestic capacities, which could then be reduced over

\footnotetext{
${ }^{5}$ Van der Gaast and Begg (2009) argue that programmatic CDM is highly suited to energy efficiency improvement projects in households (e.g. cooking, lighting) and industry (e.g. one technology applied within an industrial sector at different locations but under similar circumstances).

${ }^{6}$ The established truth that Africa and the least developed countries (LDCs) have been lagging behind in CDM project hosting is based simply on an analysis of the numbers of projects per country. Lütken (2011) suggests, however, that if more relative indicators are used, such as the size of an economy, the level of carbon emissions and CDM project development, the conclusion would have to be that Africa and the LDCs are no longer the lost world in CDM terms.

${ }^{7}$ In liberalizing trade in EGS, priority should be given to products, technologies and services used in small-scale CDM projects and programmatic CDM. In other words, such products, technologies and services should be included in any list of EGSs for accelerated liberalization. While the motivation would be to facilitate small-scale CDM projects and programmatic CDM, any agreed tariff reduction or elimination would apply to all these EGSs, irrespective of whether these are used for CDM projects. This makes it conceptually different from the Indian proposal for a project-approach that ties the liberalization of any EGS to specific projects.
} 
time to provide an incentive to manufacturers to reduce costs and eventually become globally competitive. There is no one-size-fits-all strategy for tariff liberalization for all countries and for all EGs. Some developing countries take the first course, reducing tariffs on finished products for some time to meet nationally set clean energy targets while domestic manufacturing capacities are developing. For example, South Africa has set a target to install more than three million solar water heating (SWH) systems over the five years until 2013. The government's policy is to develop local industry, but due to the lack of local production capacity, SWH systems must be imported in the short- to medium-terms to ensure that target is met (Tudor-Jones, 2009).

By contrast, some countries, in particular those countries with a sufficiently large domestic market to develop domestic manufacturing capacities across the supply chain would prefer to take the latter course. Taking that course may have short-term economic and environmental costs, but if successful, may pay off in the longer run (Wooders, 2009). For example, with regard to wind turbines, India has imposed very high tariffs with the aim of encouraging domestic production and jobs, China has put in place a local content requirement (Box 1) (Alavi, 2007; Zhang, 2008), and the Ukraine took the efforts to develop a domestic wind sector. These policies act as barriers to foreign suppliers of wind turbines, and are seen as beneficial for local wind turbine makers. However, such policies hurt home countries in financial terms. In the case of China's local content requirement, while being less costly, domestic wind turbines in China break down more often (even collapse in the worst cases (China Environment News, 2010)) and their overall capacity factors are several percentage points lower than those of foreign models. Such a few percentage points difference might not seem significant, but could well make a difference between a wind farm that is economically viable and one that is not (Zhang, 2010b). Nevertheless, such protection helped China build up its wind turbine manufacturing capacities, and has made its domestically made wind turbines globally competitive. However, not all instances of countries taking the latter course have a happy ending. In the Ukraine projects ended up being saddled with installation costs two to three times the world average, and a near complete lack of foreign private investment in the sector despite otherwise favorable conditions (Point Carbon, 2008). The Ukraine is not an exception. A study by the WTO (2004) shows that most countries open to trade adopt cleaner technologies more quickly, and increased real income is often associated with greater demand for environmental quality.

These examples suggest the need for a high degree of flexibility to accommodate different situations and stakes in the liberalization of trade in EGS. They accordingly exemplify the challenges ahead and the uncertainty about whether a deal can be concluded on a desired degree and level of such trade liberalization. Needless to say, the objective of having an agreement on EGs or a subset of EGs - such as climate-friendly goods - under WTO should be pursued as the best choice. However, should the WTO Members fail to reach such an agreement, then alternative options, ideally still under the Doha Round, ${ }^{8}$ need to be explored, although business groups have even suggested removing EGs from the Doha agenda. ${ }^{9}$

\footnotetext{
${ }^{8}$ In view of the latest developments in the Doha negotiations this would become increasingly difficult, but not impossible. Veteran trade negotiators suggest that several
} 


\section{BOX 1 LOCAL CONTENT REQUIREMENT FOR WIND POWER PROJECTS}

While China sets itself on a course of rapid development of wind power, its technology and manufacturing capacity can hardly match its demand. China has to rely on foreign turbine manufacturers. Generally speaking, huge order of turbines from China helps to expand these manufacturers' scale of production and thus reduces their cost and price of wind turbines. However, one needs to take account of the so-called phenomenon of the "China factor". When China needs something, prices go up; when China sells something, prices go down. The monopoly behaviors of these foreign turbine manufacturers keep the prices of turbines rising as China's order size is growing. China has indeed viewed itself subsidizing foreign manufacturers. A "China factor" may be acceptable for increasing oil prices associated with China's increasing demand, as oil is an exhaustible natural resource. However, it is less acceptable for wind turbines. Consequently, top Chinese policymakers added a 70 per cent local content requirement, meaning that wind power projects must have over 70 per cent of their turbine components locally made, and that the wind turbine generator must be assembled in China. The aim is to encourage technology and manufacturing industry for wind turbines in China. This requirement was originally proposed in relation to wind concession farms in China, but was extended to include ordinary wind farm projects as well in 2005. The bidding mechanism, coupled with the 70 per cent local content requirement, speeds up the localization of wind turbines. Local wind turbine makers account for an increasing share of total new installations. Now, Sinovel Wind, Goldwind Science and Technology, and Dongfang Electric, the three largest local wind turbine makers together supply over 55 per cent of a market once dominated by foreign firms until 2008. With domestic turbine makers now dominating the wind power market (supplying over 85 per cent of the Chinese market today), China abolished the local content requirement practice in November 2009.

Sources: Zhang (2010b and 2011).

An agreement similar to the Information Technology Agreement (ITA) is one option to consider. ${ }^{10}$ However, it would require a certain number of Members representing a minimum percentage of trade in climate-friendly goods and services to

smaller agreements could be salvaged from the existing negotiations, with an agreement on EGS identified as one of the four areas (Schwab, 2011).

${ }^{9}$ In a letter to United States President Barack Obama on August 3, 2009, the National Foreign Trade Council and eight other United States business groups urged his Administration to "use all possible channels" to pursue an agreement on reducing barriers to trade in EGSs, even if that meant going outside the Doha Round (Palmer, 2009).

${ }^{10}$ The problem of ensuring a consistent interpretation of customs classifications under the ITA has led to disagreements among trade negotiators as well as between customs authorities and traders, to the point that some analysts are questioning the relevance of this Agreement (Vykhylaev, 2010). 
join $^{11}$ in order for it to come into effect (World Bank, 2007). Such an agreement would be open to voluntary participation, and once in effect, the benefits of trade liberalization in climate-friendly goods and technologies would extend to all WTO Members on an MFN basis. The ITA has incorporated a mechanism for review of product coverage every three years. This may have tempered the disappointment of many countries with the initial exclusion of certain products. Given that developing countries are currently not significant suppliers of climate-friendly goods and technologies, priority should be given to additional products being submitted by developing countries for inclusion in a future review. However, the downside of this ITA mechanism is that no new products have ever been added since 1997. Thus developing countries may be suspicious of this offer for review, and feel reluctant to join.

Another option is a plurilateral agreement in this area, similar to the WTO Agreement on Government Procurement. WTO Members could opt to sign up to such an agreement or not, but the benefits of trade liberalization would extend only to participating Members on an MFN basis, unlike the aforementioned ITA-type Agreement which would extend MFN treatment to non-signatory WTO Members as well. While such a plurilateral agreement would not be ideal, it would still have value, particularly if the key trading parties were involved. Such an agreement could eventually be made multilateral once a certain number of Members representing a minimum percentage of trade in climate-friendly goods and services joined.

Other options for this sort of agreement may be within the context of regional or bilateral trade agreements. Such agreements aim to liberalize substantially all goods at the HS six-digit level. As a result, product classification and the dual-use problems associated with WTO negotiations on EGs and services may be less of a concern. These agreements would liberalize EGs fully. However, the downside of the regional or bilateral trade agreement approach is that trade may be diverted from countries that are most efficient at producing certain EGs but are excluded from those agreements. Moreover, by entailing generally the zero rating of all products, this approach would remove any tariff differential between EGs and their non-preferable like products. Whether such an elimination of tariffs in EGs would be enough to encourage their larger utilization in a competitive environment with other non-EGs would depend on their relative prices and the stringency of environmental policy in the home countries. Even if the prices of energy-efficient EGs were higher than those of their non-preferable like products, this would not necessarily put those EGs at a disadvantage. Provided energy subsidies are removed and costs are attached to emissions reductions, any higher initial costs of energy-efficient EGs may well be compensated by cost savings through energy savings over their lifetimes. The demonstration of new EGs (technologies) that a country

${ }^{11}$ It would make more sense in the context of climate change mitigation to define critical mass as a share of emissions rather as a share of trade. After all, any agreement on climate-friendly goods aims to cut GHG emissions by providing more choices at lower costs. However, this approach depends on how such climate-friendly goods are produced and what goods they would replace. However, it is much more difficult to calculate emissions than to calculate trade value/volume, and it is an area unfamiliar to WTO negotiators. Taken together, while the approach sounds very appealing theoretically, these complications would make it hard to implement, in practice. 
is not yet familiar with but has a high potential to replicate plays a role in this context as well: it is the first but crucial step in showing the effectiveness of these new EGs in cutting pollution and supporting its spin-off to the rest of the economy.

\subsection{Market Creation versus Market Access}

This paper focuses on liberalizing environmental goods and technologies through the reduction or elimination of tariffs. Undoubtedly, the results of such a tariff reduction or elimination would be positive, but would not be significant for increased uptake of these goods and technologies in developing countries. Many African countries already have very low tariffs on many environmental goods, but import few, if any, of them because of a lack of purchasing power and technical assistance. For many developing countries where there are simply not enough environmental markets or these markets are weak, what is the point of having opportunities if there are no capabilities? Clearly, creating markets for EGS is far more important than just improving market-access conditions for associated EGS (UNCTAD, 2010; Vossenaar, 2010; Vykhylaev, 2010). Put another way, market creation should take precedence over market access.

There are indications that a growing number of developing countries have established some kind of policy targets for renewable energy and are taking measures aimed at creating domestic markets for associated products and technologies. By 2010, at least 96 countries including all major economies, up from 45 countries in 2005, had set renewable energy targets in renewable energy portfolio standards or specific percentage goals of electricity production, total primary or final energy supply from renewables (REN21, 2011). Supportive policies are crucial for the widespread deployment of green energy technologies to meet that targets. The development of wind power in China shows that a policy does make a difference. With policies favorable for the development of wind power, wind power capacity in China doubled for the past five consecutive years until 2009 (Zhang 2010b and 2011). Moreover, as the development of Solar PV in Germany has shown, developing countries need more use of subsidies to create demand for EGs and enhance domestic manufacturing capacities. In the German case, while Germany has unfavorable solar radiation conditions compared with its Southern European countries, with its feed-in tariffs, it leads the world in both accumulated installations and new PV additions, with its cumulative PV installations through 2009 more than the sum of the next 9 ranked countries combined (Kazmerski, 2011).

With respect to market access, as tariffs in developed countries are already very low - generally less than 3 per cent for EGs on the OECD list (Vykhylaev, 2003) - and as not all EGs are sensitive to tariff reductions, ${ }^{12}$ the access of developing countries to developed country markets would depend more on reduction or removal of trade restrictions in the form of NTBs.

NTBs include technical standards and certification requirements, local content requirements, labelling requirements, public procurement policies in favor of domestic products, and tied-aid that requires the receipt to grant tariff preference for a donor country's goods and services, as well as tax and subsidy measures and other incentives. In some cases, subsidies and incentives have been instrumental in creating demand for

${ }^{12}$ An analysis by Jha (2008) of 84 energy supply products in the Friends' 153 EGS list reveals that only 30 per cent of those products are sensitive to a tariff reduction. 
single-use EGs, including those imported from developing countries. Most of the increase in developing-country exports of PV devices was triggered by increased EU imports, which in turn was the result of increased demand driven by incentives, in particular feedin tariffs. In 2008, EU imports accounted for more than half the value of world imports, three quarters of which originated in developing countries. In the case of wind turbines, US imports accounted for almost two thirds of the increase in world trade in the period 2004-2008 (Vossenaar, 2010). In many cases, however, NTBs are considered significant impediments to developing countries' access to developed country markets. They might be implemented in such a way as to favor domestic producers over foreign ones. Such differential treatment could occur in governing eligibility for, and the amount of, a subsidy, in establishing energy efficiency standards, in determining the category of eco-labeled products and the procedures for establishing eco-labels, and in specifying criteria for tenders and conditions for participating in government procurement bids such as "Buy American” type of provisions which creates biases for US home-made goods under the US stimulus package (Zhang and Assunção, 2004). Developing countries constantly refer to intellectual property rights as a barrier to access to much-needed and advanced lowcarbon technologies, in addition to their high licensing fees or royalty payments. All this suggests that high tariffs are only one of the factors that determine access to and affordability of climate-friendly goods and technologies, and thus that action beyond tariff reduction or elimination is also needed to achieve the desired effect. However, Members' submissions on NTBs related to environmental goods have thus far been quite general. They simply indicate sectors where there could be potential NTBs. A lot of work is still required in this area to identify measures with any real degree of specificity, with one suggestion along this line being Mauritius's submission to include NTBs in the category-by-category exercise (ICTSD, 2011).

\section{Conclusions}

Paragraph 31(iii) of the DMD mandates the liberalization of environmental goods and services. This mandate offers a good opportunity to put climate-friendly goods and services on a fast track to liberalization. Agreement on this paragraph should represent one immediate contribution that the WTO can make to fight against climate change, one of the world's most pressing long-term threats to future prosperity and security.

Under current negotiations on the liberalization of trade in EGs in the CTE-SS, the approach to defining the universe of EGs covered still remains open, with options ranging from adopting an agreed set of EGs, undertaking a request-offer process to reduce tariffs to these products, or providing concessions for goods used in environmental projects, for instance under the Clean Development Mechanism. Some WTO Members have submitted lists of environmental goods with a view to creating a WTO-agreed list of such goods that would then be turned over to the NAMA negotiating group to negotiate tariff reductions and/or elimination. While significant progress has been achieved, much work remains on environmental goods. Members still disagree over how to decide which EGs should be subject to trade liberalization. As a potential way forward, countries would need to examine the possibility of a hybrid approach combining aspects of the different approaches that have thus far been proposed. A list of products 
would be coupled with project-specific liberalization for goods that may not have qualified for the list but are being used in an environmental project under the Clean Development Mechanism. This could be complemented by a request-offer process for products where there is no agreement (ICTSD, 2011). Whatever the approaches to the EG negotiations, it will be important to have accuracy of HS classification and descriptions and clear ex-outs. This issue is crucial to clarify product coverage and descriptions, but is still unresolved.

Moreover, under the negotiating structure of the Trade Negotiations Committee, the negotiations on EGs are pursued in parallel tracks. As a result, the pace of these negotiations continues to be tied to progress in other negotiating groups, in particular to the NAMA negotiations whose progress remains sluggish. Clearly, progress in the NAMA negotiations will boost negotiations on EGs. However, if progress in the NAMA negotiations remains slow, the question then arises in this context: should negotiations on EGs continue to take place in the Negotiating Group on NAMA? Progress in negotiations on tariff reduction and/or elimination for an agreed list of EGs might move faster if they were separated from the broader talks on NAMA. However, moving in this desirable direction would face a significant challenge, given the fact that the Doha Round mandates a single undertaking, which implies that nothing is considered agreed until everything is agreed. $^{13}$

Talks on WTO EGSs need a boost from other areas as well. Effective technology transfer and financial mechanisms are widely believed to have played a decisive role in making the Montreal Protocol work effectively (Brack, 1996; Zhang, 2009). Given that the scope of economic activities affected by a climate regime is several orders of magnitude larger than those covered by the Montreal Protocol, technology transfer and deployment, financing and capacity-building are considered to be even more essential components of any post-2012 climate change agreement that developing countries would agree upon to succeed the Kyoto Protocol. Moreover, the Joint Working Party on Trade and the Environment at the OECD (2009) stresses a lack of appreciation of how large the stakes are in the EGS negotiations as the obstacle to obtaining an agreement on the liberalization of trade in EGS, which is attributed to a lack of more stringent climate commitments of broader scope. If and when such a post-2012 climate change deal is reached, it would significantly enhance the possibilities of a breakthrough in reaching an EGSs deal under the WTO. As aforementioned, most of the increase in developing country exports of PV devices and wind turbines between 2004 and 2008 was largely driven by regulations that mandate specific shares of renewable energy in the total energy supply, favorable feed-in tariffs and other incentives in developed countries. If history provides any indication, a post-2012 climate change deal, once reached, will create the urgent need for low-cost climate-friendly goods and services and thus drive their market development at a pace and on scale unprecedented with the existing regulations and incentives in developed countries.

${ }^{13}$ This rule was designed to encourage countries to make tough calls in one sector knowing that they would be able to show gains in other sectors. However, in the context of the Doha Round, the rule has enabled individual countries to play the spoiler and seek the lowest common denominator outcomes or to free ride on others' concessions (Schwab, 2011). 
Discussions throughout the paper illustrate that there is no one-size-fits-all strategy for tariff liberalization for all countries and for all EGs. This suggests the need for a high degree of flexibility to accommodate different situations and stakes in the liberalization of trade in EGs, and accordingly exemplifies the challenges ahead and the uncertainty about the negotiations on the desired degree and level of such trade liberalization. Needless to say, the objective of having an agreement on EGs or a subset of EGs - such as climate-friendly goods - under the WTO should be pursued as the best choice. However, should WTO Members fail to reach such an agreement, alternative options, which are ideally still under the Doha Round although in view of the latest developments in the Doha negotiations this would become increasingly difficult, need to be explored. An agreement similar to the Information Technology Agreement is one option to consider. Another option is a plurilateral agreement similar to the WTO Agreement on Government Procurement. Other options may be within the context of regional or bilateral trade agreements. Such agreements aim to liberalize substantially all goods at the HS six-digit level. As a result, product classification and the dual-use problems associated with WTO negotiations on EGs and services may be less of a concern.

Finally, it should be emphasized that tariff reduction or elimination alone for EGS will have little effect on their use if it is not implemented as an integral part of broader policies and strategies. This is simply because there are not enough environmental markets or these markets are weak in many developing countries. Therefore, creating markets for EGS in developing countries is far more important than just improving market-access conditions for associated EGS. There is a positive sign that a growing number of developing countries have established some kind of policy targets for renewable energy and are taking measures aimed at creating domestic markets for associated products and technologies. Given that the access of developing countries to developed country markets would depend more on reduction or removal of trade restrictions in the form of NTBs, there is a need to consider other efforts rather than adopting an exclusive focus on tariff reduction or elimination in order to serve the best interests of developing countries and enable them to access both climate-friendly goods and technologies at an affordable price and developed country markets. Special and differential treatment provisions will also be essential to take into account the concerns of developing countries. These include less than full reciprocity in terms of an exemption from or a lower level of reduction commitment, as suggested for a development list in China's submission, and flexibility in terms of longer implementation periods - or both for developing countries, and optional participation for least developed countries. In addition, a package of technical and finance assistance is badly needed to ensure that all developing countries are able to benefit from the rapidly growing world market for climate-friendly goods and technologies. At least one WTO developed country Member Canada - in its submission has recognized the importance of such assistance and has pledged to provide it (Canada, 2005). All these aforementioned initiatives should be made part of the EGs package for it to work. 


\section{Acknowledgements}

This paper grows from a short piece (Zhang, 2010a) in Trade and Environment Review 2009/2010, a flagship publication of the United Nations Conference on Trade and Development (UNCTAD) every three years. It has benefited from helpful comments from Ulrich Hoffmann and Darlan F. Martí and work in this area from International Centre for Trade and Sustainable Development (ICTSD). That said, the views expressed here are those of the author, and do not reflect the positions of the UNCTAD and ICTSD. The author bears sole responsibility for any errors and omissions that may remain.

\section{References}

Alavi, R. (2007), 'An overview of key markets, tariffs and non-tariff measures on Asian exports of select environmental goods', ICTSD Trade and Environment Series Issue Paper No.4, International Centre for Trade and Sustainable Development (ICTSD), Geneva.

Argentina (2005), 'Integrated proposal on environmental goods for development', Submission to the World Trade Organization, TN/TE/W/62, October.

Argentina (2009), 'The Doha Round and climate change', Submission to the World Trade Organization - Paragraph 31(iii), TN/TE/W/74, November.

Argentina and Brazil (2010), 'Environmental goods and services paragraph 31(iii) -special and differential treatment, communication from Argentina and Brazil', Submission to the World Trade Organization, TN/TE/W/76, June.

Bora, B. and T. Robert (2004), 'Tariffs and trade in environmental goods', Presented at the Workshop on Environmental Goods, organized by WTO Secretariat, Geneva, 11 October.

Brack, D. (1996), International Trade and the Montreal Protocol, London: The Royal Institute of International Affairs and Earthscan.

Brazil (2007), 'Committee on Trade and Environment (Special Session), submission by Brazil - Paragraph 31(iii)’, JOB(07)/146, October.

China (2004), 'Statement on environmental goods at the CTESS meeting of 22 June 2004, Geneva', Submission to the World Trade Organization, TN/TE/W/42, July.

China Environment News (2010), 'National Energy Administration initiates a thorough investigation into the equipment quality reacting to frequent collapses of domestic wind turbines', Sina Net, 6 December, available at: http://finance.sina.com.cn/chanjing/cyxw/20101206/09319059835.shtml.

Canada (2005), 'Canada's initial list of environmental goods', Submission to the World Trade Organization, TN/TE/W/55, July.

Cuba (2005), 'Environmental goods', Submission to the World Trade Organization, TN/TE/W/50, June.

Hamwey, R. (2005), 'Environmental goods: where do dynamic trade opportunities for developing countries lie?', Working Paper, Centre for Economic and Ecological Studies, Geneva.

Harashima, Y. (2008), 'Trade and environment negotiations in the WTO: Asian perspectives', International Environmental Agreements: Politics, Law and Economics, 8 (1), 17-34. 
Howse, R. and P. van Bork (2006), 'Options for liberalizing trade in environmental goods in the Doha Round', Trade and Environment Series Issue Paper No.2, International Centre for Trade and Sustainable Development, Geneva.

ICTSD (2007a), 'EU, US call for eliminating trade barriers to climate-friendly goods and services', International Centre for Trade and Sustainable Development (ICTSD), Geneva, 18 December, available at: http://ictsd.net/i/news/biores/9151/.

ICTSD (2007b), 'Brazil Peru discuss new ideas on environmental goods liberalisation', International Centre for Trade and Sustainable Development (ICTSD), Geneva, 16 November, available at: http://ictsd.net/i/news/biores/9144/.

ICTSD (2007c), 'Bali climate conference: the next two years will tell', International Centre for Trade and Sustainable Development (ICTSD), Geneva, November, available at: http://ictsd.net/i/news/bridges/3159/.

ICTSD (2008), 'Liberalization of trade in environmental goods for climate change mitigation: the sustainable development context', International Centre for Trade and Sustainable Development (ICTSD), Geneva.

ICTSD (2011), 'WTO environmental goods talks find way forward', Bridges Weekly Trade News Digest, 15 (1), 6-7.

India (2005a), 'An alternative approach for negotiations under paragraph 31(iii)', Submission to the World Trade Organization, TN/TE/W/51, June.

India (2005b), 'Structural dimensions of the environmental project approach', Submission to the World Trade Organization, TN/TE/W/54, July.

Intergovernmental Panel on Climate Change (IPCC) (2007), Climate Change 2007: Mitigation of Climate Change, Working Group III Contribution to the Fourth Assessment Report, Cambridge, UK: Cambridge University Press.

Jackson, J.H. (2000), 'Comments on shrimp/turtle and the production/process distinction', European Journal of International Law, 11 (2), 303-307.

Japan Ministry of the Environment (2008), 'White paper on the environment', Tokyo. Jha, V. (2008), 'Environmental priorities and trade policies for environmental goods: a reality check', Trade and Environment Series Issue Paper No.7, International Centre for Trade and Sustainable Development, Geneva.

Kazmerski, L.L. (2011), 'Solar photovoltaics: no longer an outlier', in F. Fesharaki, N.Y. Kim, Y.H. Kim and Z.X. Zhang (eds), Global Dynamics in the Green Energy Industry: A New Engine of Growth, Seoul: Korean Energy Economics Institute Press, pp. 48-80.

Kim, J.A. (2007), 'Issues of dual use and reviewing product coverage of environmental goods', Trade and Environment Working Papers No. 2007/1, Organization for Economic Cooperation and Development, Paris.

Lamy, P. (2008), 'A consensual international accord on climate change is needed', Presented to the Temporary Committee on Climate Change, The European Parliament, Brussels, 29 May, available at: http://www.wto.org/english/news_e/sppl_e/sppl91_e.htm.

Lamy, P. (2009), 'Climate first, trade second - GATTzilla is long gone', Keynote Address at the Carleton University, 2 November, Ottawa, Canada, available at: http://www.wto.org/english/news_e/sppl_e/sppl140_e.htm.

Lütken, S. (2011), 'Indexing CDM distribution: leveling the playing field', Capacity Development for the Clean Development Mechanism CD4CDM Working Paper 
Series No. 10, May, available at:

http://www.cd4cdm.org/Publications/IndexingCDMdistribution.pdf.

Morici, P. (2002), Reconciling Trade and the Environment in the WTO, Washington, DC: Economic Strategy Institute.

OECD (2005), “The environmental goods and services industry', Organization for Economic Cooperation and Development (OECD), Paris.

OECD (2009), 'Report on the Global Forum on Trade and Climate Change of 9-19 June 2009, Paris', Joint Working Party on Trade and the Environment, Organization for Economic Cooperation and Development (OECD), Paris.

OECD and Eurostat (1999), 'The environmental goods and services industry: manual on data collection and analysis', Organization for Economic Cooperation and Development (OECD), Paris.

Palmer, D. (2009), 'Remove environmental goods talks from Doha: U.S. groups', Reuters, 4 August, available at: http://www.reuters.com/article/GCAGreenBusiness/idUSTRE5725Z520090804.

Paulsson, E. (2009), 'A review of the CDM literature: from fine-tuning to critical scrutiny?', International Environmental Agreements: Politics, Law and Economics, 9 (1), 63-80.

Point Carbon (2008), 'Clean energy investment in the former Soviet Union region (Ukraine and Kazakhstan): the domestic context', International Institute for Sustainable Development, Winnipeg, Canada, available at: http://www.iisd.org/pdf/2008/cei_ukraine_kazakhstan.pdf.

Renewable Energy Policy Network for the 21st Century (REN21, 2011), Renewables 2011 Global Status Report, Paris.

Qatar (2003), 'Negotiations on environmental goods: efficient, lower-carbon and pollutant-emitting fuels and technologies', Submission to the World Trade Organization, TN/TE/W/19, January.

Schwab, S.C. (2011), 'After Doha: why the negotiations are doomed and what we should do about it', Foreign Affairs, 90 (3), 104-117.

Singh, S. (2005), 'Environmental goods negotiations: issues and options for ensuring win-win outcomes', International Institute for Sustainable Development, Winnipeg, Canada, June.

Steenblik, R. (2005), 'Environmental goods: a comparison of the APEC and OECD lists', The OECD Joint Working Party on Trade and Environment, COM/ENV/TD(2003)10/FINAL, Organization for Economic Cooperation and Development, Paris, available at: http://www.oecd.org/dataoecd/44/3/35837840.pdf.

Steenblik, R., Drouet, D. and G. Stubbs (2005), 'Synergies between trade in environmental services and trade in environmental goods', The OECD Joint Working Party on Trade and Environment, COM/ENV/TD(2004)23/FINAL, Organization for Economic Cooperation and Development, Paris, available at: http://www.oecd.org/dataoecd/21/48/35161237.pdf.

Tudor-Jones, D. (2009), 'Solar', presented at the WTO Workshop on Environmental Goods and Services, Geneva, 23-25 September, available at: http://www.wto.org/english/tratop_e/envir_e/wksp_goods_sept09_e/tudorjones_e. pdf. 
UK Department for Business Enterprise and Regulatory Reform (2009), Low Carbon and Environmental Goods and Services: An Industry Analysis.

UNCTAD (1995), 'Environmentally preferable products (EPPs) as a trade opportunity for developing countries', UNCTAD/COM/70, United Nations Conference on Trade and Development (UNCTAD), Geneva.

UNCTAD (2005), 'Environmental goods: identifying items of export interest to developing countries’, CBTF Briefing Note, United Nations Conference on Trade and Development (UNCTAD), Geneva.

UNCTAD (2010), The Green Economy: Trade and Sustainable Development Implications, UNCTAD/DITC/TED/2010/2, Geneva: United Nations Conference on Trade and Development (UNCTAD).

UNEP Ozone Secretariat (2000), 'The Montreal Protocol on Substances that Deplete the Ozone Layer’, United Nations Environment Programme (UNEP), Nairobi, Kenya, available at: http://ozone.unep.org/pdfs/Montreal-Protocol2000.pdf.

UNEP Risoe Center (2011), 'CDM and JI pipelines by September 1', Denmark, available at: http://www.cdmpipeline.org/publications/CDMpipeline.xlsx.

USITC (2009), 'Wind turbines, industry and trade summary', United States International Trade Commission (USITC), Office of Industries, Publication ITS-02, Washington DC, June.

Van der Gaast, W. and K. Begg (2009), 'Enhancing the role of the CDM in accelerating low-carbon technology transfers to developing countries', Carbon and Climate Law Review, 3 (1), 58-68.

Vikhlyaev, A. (2003), 'Environmental goods and services: defining negotiations or negotiating definitions', in United Nations Conference on Trade and Development, Trade and Environment Review 2003, Geneva, pp. 33-60.

Vikhlyaev, A (2010), 'WTO negotiations on environmental goods and services: the case of renewables', in United Nations, Trade and Environment Review 2009/2010: Promoting Poles of Clean Growth to Foster the Transition to a More Sustainable Economy, UNCTAD/DITC/TED/2009/2, Geneva, Switzerland: United Nations Conference on Trade and Development, pp. 184-193.

Vossenaar, R. (2010), 'Climate-related single-use environmental goods’, ICTSD Programme on Trade and Environment Issue Paper No. 13, International Centre for Trade and Sustainable Development (ICTSD), Geneva, September.

WCO (2003), 'Annual survey to determine the percentage of government revenue provided customs duties', Document No. NC0655, World Customs Organization (WCO), Brussels.

Wooders, P. (2009), 'Greenhouse gas emissions impacts of liberalizing trade in environmental goods and services', International Institute for Sustainable Development, Winnipeg, Canada, October.

World Bank (2007), International Trade and Climate Change: Economic, Legal and Institutional Perspectives, Washington, DC: World Bank.

WTO (2002), 'List of environmental goods -- paragraph 31 (iii)', Note by the Secretariat, TN/TE/W/18, World Trade Organization (WTO), Geneva, 20 November.

WTO (2004), 'Trade and environment at the WTO', background paper, World Trade Organization (WTO), Geneva. 
WTO (2005), 'Synthesis of submissions on environmental goods', Informal Note by the Secretariat, Committee on Trade and Environment Special Session, TN/TE/W/63, World Trade Organization (WTO), Geneva, available at: http://www.jmcti.org/2000round/com/doha/tn/te/tn_te_w_063.pdf.

Zhang, Z.X. (1998), 'Greenhouse gas emissions trading and the world trading system', Journal of World Trade, 32 (5), 219-239.

Zhang, Z.X. (2004), 'Open trade with the U.S. without compromising Canada's ability to comply with its Kyoto Target', Journal of World Trade, 38 (1), 155-182.

Zhang, Z.X. (2008), 'Asian energy and environmental policy: promoting growth while preserving the environment', Energy Policy, 36, 3905-3924.

Zhang, Z.X. (2009), 'Multilateral trade measures in a post-2012 climate change regime?: what can be taken from the Montreal Protocol and the WTO?', Energy Policy, 37, 5105-5112.

Zhang, Z.X. (2010a), 'Liberalizing climate-friendly goods and technologies in the WTO: product coverage, modalities, challenges and the way forward', in United Nations, Trade and Environment Review 2009/2010: Promoting Poles of Clean Growth to Foster the Transition to a More Sustainable Economy, UNCTAD/DITC/TED/2009/2, Geneva, Switzerland: United Nations Conference on Trade and Development, pp. 178-183.

Zhang, Z.X. (2010b), 'China in the transition to a low-carbon economy', Energy Policy, 38, 6638-6653.

Zhang, Z.X. (2010c), 'The U.S. proposed carbon tariffs, WTO scrutiny and China's responses', International Economics and Economic Policy, 7 (2-3), 203-225.

Zhang, Z.X. (2011), Energy and Environmental Policy in China: Towards a Low-Carbon Economy, New Horizons in Environmental Economics Series, Cheltenham, UK and Northampton, USA: Edward Elgar.

Zhang, Z.X. and L. Assunção (2004), 'Domestic climate policy and the WTO', The World Economy, 27 (3), 359-386.

Zhang, Z.X. and A. Maruyama (2001), 'Towards a private-public synergy in financing climate change mitigation projects’, Energy Policy, 29, 1363-1378. 